\title{
KONTRIBUSI GAYA KEPEMIMPINAN, KOMPETENSI PROFESIONAL, DAN KOMPETENSI MANAJERIAL KEPALA SEKOLAH TERHADAP MOTIVASI KERJA GURU (STUDI TENTANG PERSEPSI GURU SMAN 1 MENGWI)
}

\author{
Suardana I Putu, Made Yudana 1, Anak Agung Gede Agung 2 \\ Jurusan Administrasi Pendidikan, Program Pascasarjana \\ Universitas Pendidikan Ganesha \\ Singaraja, Indonesia
}

e-mail: \{putu.suardana, made.yudana, gede.agung\} @pasca undiksha.ac.id

\begin{abstract}
Abstrak
Penelitian ini bertujuan untuk mengetahui hubungan gaya kepemimpinan, kompetensi profesional dan kompetensi manajerial kepala sekolah terhadap motivasi kerja guru SMA Negeri 1 Mengwi secara terpisah maupun simultan. Populasi penelitian ini adalah seluruh Siswa SMA Negeri 1 Mengwi dengan jumlah sebanyak 70 orang siswa. Penelitian ini menggunakan rancangan ex-post facto. Data dikumpulkan dengan kuesioner dan lembar observasi. Data dianalisis dengan regresi, korelasi dan analisis kontribusi. Hasil penelitian menunjukkan bahwa: (1) Terdapat kontribusi yang signifikan antara gaya kepemimpinan terhadap motivasi kerja guru dengan kontribusi sebesar 45,10 $\%$ dan sumbangan efektif sebesar $16,80 \%$, (2) Terdapat kontribusi yang signifikan antara kompetensi profesional terhadap motivasi kerja guru dengan kontribusi sebesar 50,60\% dan sumbangan efektif sebesar 30,40\%, (3) Terdapat kontribusi yang signifikan antara kompetensi manajerial Kepala Sekolah terhadap motivasi kerja guru dengan kontribusi sebesar $39,20 \%$ dan sumbangan efektif sebesar $24,90 \%$, dan (4) Terdapat kontribusi yang signifikan secara bersamasama antara gaya kepemimpinan, kompetensi profesional, dan kompetensi manajerial Kepala Sekolah terhadap motivasi kerja guru dengan kontribusi sebesar $72,10 \%$. Berdasarkan hasil temuan tersebut dapat disimpulkan bahwa terdapat hubungan yang signifikan antara gaya kepemimpinan, kompetensi profesional dan kompetensi manajerial kepala sekolah terhadap motivasi kerja guru SMA Negeri 1 Mengwi secara terpisah maupun simultan.
\end{abstract}

Kata kunci: gaya kepemimpinan, kompetensi profesional, kompetensi manajerial kepala sekolah, motivasi kerja guru.

Abstract

This research is aimed at knowing the relation of tipycal leadership,professional Competence, and Managerial Competence of school headmaster toward teachers work motivation of SMA Negeri 1 Mengwi. There are 70 teachear, this research uses ex - post facto design. Data has been collected by applying questioner and observation sheet. The data was analyzed by regression, correlation and contribution analysis. The result of the research shows that : (1) There is a significant correlation between typical leadership toward teachers work motivation with efectiv donation as much as $16,80 \%,(2)$ There is significant contribution between professional competence toward teachers work motivation with effective donation as much as $30,40 \%$, (3) There is a significant contribution between managerial competence of headmaster toward teachers work motivation with effective donation as much $24,90 \%$, and (4) There is contribution which is significant and simultenously between typical leadership,professional competence, and managerial competence of the headmaster toward teachers work motivation with the contribution as much as $72,10 \%$. Based on the result of the discovery, it can be concluded that there is relation which is significant enough between typical leadership, professional competence and the headmaster managerial competence toward teachers work motivation of SMA Negeri 1 Mengwi separately or simultaneously.

Key word: The Typical Leadership, Professional Competence, Managerial Competence of the headmaster, teacher motivation. 


\section{PENDAHULUAN}

Perbaikan kualitas pendidikan tidak terlepas dari peran kepala sekolah sebagai pemegang kebijakan yang mampu menciptakan motivasi kerja yang kondusip. Dalam proses pembelajaran, motivasi sangatlah diperlukan sebab biasanya seseorang yang tidak mempunyai motivasi kerja tidak akan melakukan aktifitas belajar dengan efektif. Motivasi berasal dari kata motif yang berarti tenaga diri dalam diri manusia yang menyebabkan individu mau bergerak atau bekerja (Soerjabrata, 1981). Senada dengan Sardiman (1990) berpendapat, motif adalah daya dorong seseorang untuk melakukan sesuatu. Dengan demikian, motivasi adalah daya penggerak seseorang agar mau melakukan aktivitasaktavitas tertentu demi terciptanya suatu tujuan sejalan dengan itu, Mataheru (1985/1986) menyatakan motivasi berasal dari kata latin movere yang berarti to move atau menggerakkan. Selanjutnya Terry (1991) mengatakan bahwa motivasi adalah upaya agar seseorang dapat menyelesaikan pekerjaan dengan semangat.

Dalam pengertian yang lebih umum Hoy dan Miskel (1987) mengemukakan, motivasi mengacu pada proses penentuan pilihan oleh seorang individu diantara berbagai bentuk aktivitas yang bersifat sukarela. Dalam hal ini, Luthans (1981) mengutarakan bahwa merupakan kebutuhan, keinginan maupun dorongan. Dengan demikian, berdasarkan pandangan-pandangan tersebut di atas, dapat dikatakan bahwa motivasi adalah kondisi intrinsik maupun ektrinsik yang menjadi penggerak bagi seseorang untuk mau dan ingin melakukan sesuatu. Dengan demikian motivasi kerja adalah keseluruhan kondisi intrinsik maupun ektrinsik yang menjadi tenaga penggerak sehingga seseorang mau bekerja sesuai dengan harapan. Kondisi ini misalnya pemenuhan kebutuhan (Buford \& Bedeian, 1988) baik kebutuhan materi maupun non materi (Siagian, 1983), dengan pemenuhan kebutuhan tersebut, akan menimbulkan dorongan yang kuat menggerakkan individu untuk mencapai tujuan (Zukdi, 1996). Ini mengandung makna, bahwa semakin besar motivasi kerja akan semakin besar peluang mencapai tujuan pendidikan yang telah ditetapkan.

Sehingga menjadi jelalslah bahwa motivasi berfungsi untuk mendorong manusia bekerja, mengarahkan kerjanya, dan menyeleksi perbuatannya, untuk mencapai tujuan (Purwanto, 1987) dalam kaitannya dengan ini, Hoy dan Miskel (1987) menyebutkan motivasi terdiri atas tiga komponen, yaitu mengaktifkan tingkah laku, mengarahkan tingkah laku, dan mempertahankan tingkah laku. Ini berarti motivasi akan mengarahkan tingkah laku serta bagaimana memperthankannya. (Steers \& Porter, 1983). Berpedoman dari beberapa pandangan tersebut diatas, jelaslah motivasi memegang peranan penting dalam bekerja. Guru yang bermotivasi tinggi akan berusaha sekuat tenaga untuk meningkatkan kinerjanya sehingga pengelolaan pembelajaran dikelas akan meningkat. Jadi pengelolaan pembelajaran Bahasa Bali di kelas akan menjadi optimal kalau ada motivasi. Makin tepat motivasi yang diberikan, akan makin berhasil pula pelajaran itu. Perlu ditegaskan bahwa motivasi bertalian dengan suatu tujuan. Sehubungan dengan hal tersebut ada tiga fungsi motivasi yaitu: (1) mendorong manusia untuk berbuat, jadi sebagai penggerak atau motor yang melepaskan energi. Motivasi dalam hal ini merupakan motor penggerak dari setiap kegiatan yang akan dikerjakan, (2) menentukan arah perbuatan, yakni ke arah tujuan yang hendak dicapai. Dengan demikian motivasi dapat memberikan arah dan kegiatan yang harus dikerjakan sesuai dengan rumusan tujuannya, dan (3) menyeleksi perbuatan, yakni menentukan perbuatan-perbuatan apa yang harus dikerjakan yang serasi guna mencapai tujuan, dengan menyisihkan perbuatan-perbuatan yang tidak bermanfaat bagi tujuan tersebut.

Ketercapaian tujuan pendidikan sangat bergantung pada kecakapan dan kebijaksanaan kepemimpinan kepala sekolah yang merupakan salah satu pemimpin pendidikan. Karena kepala sekolah merupakan seorang pejabat yang profesional dalam organisasi sekolah yang bertugas mengatur semua sumber organisasi dan bekerjasama dengan guru-guru dalam mendidik siswa untuk mencapai tujuan pendidikan. Dengan keprofesionalan kepala sekolah ini, pengembangan profesionalisme tenaga kependidikan mudah dilakukan karena sesuai dengan fungsinya, kepala sekolah memahami kebutuhan 
sekolah yang dipimpin sehingga kompetensi guru tidak hanya terbatas pada kompetensi yang ia miliki sebelumnya, melainkan bertambah dan berkembang dengan baik sehingga profesionalisme guru akan terwujud.

Gaya kepemimpinan seseorang dalam hal ini kepala sekolah juga sangat mempengaruhi kondisi kerja, akan berhubungan dengan bagaimana bawahan (guru) menerima suatu gaya kepeminpinan yang diwujudkan dalam bentuk senang atau tidak (Suroso, 2002). Lebih lanjut dikemukakan bahwa gaya kepemimpinan tertentu juga dapat menyebabkan peningkatan kinerja atau sebaliknya dapat menurunkan kinerja. Oleh karena itu, untuk mempertahankan dan meningkatkan motivasi kerja diperlukan seorang pemimpin yang menggunakan gaya kepemimpinan situasional, yaitu pemimpin yang mernpunyai kemampuan pribadi dan mampu membaca keadaan bawahan dalam hal ini guru serta lingkungannya (Hersey dan Blanchard, 2000). Kematangan bawahan akan berkaitan langsung dengan gaya kepemimpinan yang tepat untuk diterapkan. Gaya kepemimpinan adalah pola perilaku konsisten yang diterapkan seorang pemimpin dalam mempengaruhi orang lain (Hersey dan Blanchard, 2000). Lebih lanjut dikemukakan bahwa pola perilaku yang diperlihatkan pemimpin pada saat mempengaruhi orang lain, adalah seperti yang tampak dan dirasakan pengikutnya. Gaya bukanlah soal bagaimana pendapat pemimpin tentang perilaku mereka sendiri dalam memimpin dan kenemirnpinannya. Melalui gaya kepemimpinan yang dimiliki. pemimpin akan mentransfer nilai-nilai seperti: penekanankelompok, dukungan orang/pegawai, dan toleransi terhadap resiko. Namun pada sisi lain, pegawai akan membentuk suatu persepsi subjektif mengenai dasar-dasar nilai yang ada dalam organisasi sesuai dengan nilai-nilai yang disampaikan pemimpin melalui gaya kepemimpinannya. Jadi, gaya kepemimpinan kepala sekolah. mewarnai eksistensi sekolah dan motivasi kerjanya.

Teori Fiedler dijelaskan oleh Sumidjo (1994) bahwa kepemimpinan adalah proses bagaimana kemampuan pemimpin dalam menyesuaikan pendekatan, kepribadian dan gaya kepemimpinan dengan situasi dan tugas kelompok yang ada. Kepemimpinan kepala sekolah yang baik, harus bisa menggunakan gaya kepemimpinan yang tepat sesuai dengan situasi dan kondisi kerja guru, serta bisa menumbuhkan motivasi kerja guru. Pada dasamya motivasi kerja guru berbeda-beda tingkatannya, masing-masing pribadi memiliki motivasi yang berbeda dalam bekerja. Hal $\mathrm{ml}$ disebabkan banyak faktor, baik yang timbul dari dalam individu maupun luar individu termasuk gaya kepemimpinan kepala sekolah. Motivasi adalah proses psikologis yang terjadi pada diri seseorang akibat adanya interaksi antara sikap, kebutuhan, kepuasan dan persepsi seseorang dengan lingkungan' (Sumidjo 1994 396). Motivasi kerja guru merupakan dorongan secara sadar melakukan tugas dan tanggung jawabnya karena kebutuhan, sikap, kepuasan dan persepsi seseorang dengan lingkungannya. Motivasi kerja guru bisa meliputi prestasi kerja. pengakuan yang diterima pekerjaan itu sendiri, tanggung jawab,pengembangan potensi individu. Sehingga motivasi kerja guru meningkat.

Dengan kemampuan manajerial yang dimilikinya, kepala sekolah dapat berupaya untuk mendeterminasi kompetensi profesional dari organisasi yang dipimpinnya, yang pada akhirnya akan berdeterminasi pula terhadap bawahanya. Oleh karena itu, kemampuan manajerial kepala sekolah merupakan salah satu faktor penting dalam mendeterminasi motivasi kerja guru. Karena keterampilan manajerial kepala sekolah sebagai salah satu faktor penting dalam suatu organisasi sekolah, maka seorang kepala sekolah harus mempunyai potensi dan keterampilan manajerial yang baik dan berkualitas sehingga mampu menjamin keberhasilan dari kerja atau tugas yang dipercayakan kepadanya sesuai dengan ketentuan secara fisik maupun realisasi keuangannya. Namun bila ketrampilan manajerial yang dimiliki oleh seorang kepala sekolah sangat terbatas, maka tidak menutup kemungkinan melemahnya kepercayaan yang diberikan bawahan kepadanya dalam melaksanakan tugas yang dipikulnya yang disebabkan karena adanya kekhawatiran tentang hasil akhir dari kerja kepala sekolah yang tidak maksimal. 
Motivasi kerja guru juga dipengaruhi oleh faktor kompetensi professional. Kompetensi guru merupakan seperangkat pengetahuan, keterampilan, dan perilaku yang harus dimiliki, dihayati, dikuasai, dan diaktualisasikan oleh guru dalam melaksanakan tugas keprofesionalan. Berdasarkan Peraturan Pemerintah (PP) Nomor 18 Tahun 2007 tentang guru, dinyatakan bahwasanya kompetensi yang harus dimiliki oleh Guru meliputi kompetensi profesional, kompetensi kepribadian, kompetensi sosial, dan kompetensi pedagogik yang diperoleh melalui pendidikan profesi. Kompetensi guru tersebut bersifat menyeluruh dan merupakan satu kesatuan yang satu sama lain saling berhubungan dan saling mendukung. Kompetensi profesional yang dimaksud antara lain kemampuan pemahaman tentang peserta didik secara mendalam dan penyelenggaraan pembelajaran yang mendidik. Pemahaman tentang peserta didik meliputi pemahaman tentang psikologi perkembangan anak, sedangkan pembelajaran yang mendidik meliputi kemampuan merancang pembelajaran, mengimplemen-tasikan pembelajaran, menilai proses dan hasil pembelajaran, dan melakukan perbaikan secara berkelanjutan.

Kompetensi itu pada dasarnya merupakan suatu sifat (karakteristik) orang-orang kompeten yang memiliki kecakapan, daya, kemampuan, otoritas (kewenangan), kemahiran (keterampilan), pengetahuan dan lain-lain untuk mengerjakan apa yang diperlukan. Kompetensi itu menunjukkan kepada tindakan (kinerja) rasional yang dapat mencapai tujuan-tujuannya secara memuaskan berdasarkan kondisi (prasarat) yang diharapkan. Kompetensi itu dipandang sebagai pilar teras kinerja dari sesuatu profesi.

Menurut Cooper (dalam Satori, 2000) kompetensi profesional guru terbagi dalam empat komponen yaitu: (1) mempunyai pengetahuan tentang belajar dan tingkah laku manusia; (2) mempunyai dan menguasai pengetahuan bidang studi yang dibinanya; (3) mempunyai sikap yang tepat tentang diri sendiri, sekolah, teman sejawat dan bidang studi yang dibinanya; dan (4) mempunyai keterampilan dalam teknik mengajar.

Itu berarti, kompetensi profesional merupakan kemampuan yang berkenaan dengan penguasaan materi pembelajaran bidang studi secara luas dan mendalam yang mencakup penguasaan substansi isi materi kurikulum mata pelajaran disekolah dengan substansi keilmuan yang menaungi materi kurikulum tersebut, serta menambah wawasan keilmuan sebagi guru. Muchlas (2006) secara rinci masing-masing elemen kompetensi tersebut memiliki sub kompetensi dan indikator esensial sebagai berikut: (1) menguasai substansi keilmuan sosial dan ilmu lain yang terkait bidang studi. Sub kompetensi ini memiliki indikator esensial: memahami materi ajar yang ada dalam kurikulum sekolah, memahami struktur, konsep dan metode keilmuan yang menaungi atau koheren dengan materi ajar, memahami hubungan konsep antar mata pelajaran terkait dan menerapkan konsep-konsep keilmuan dalam kehidupan sehari-hari; dan (2) menguasai langkah-langkah penelitian dan kajian kritis untuk menambah wawasan dan memperdalam pengetahuan/ materi bidang studi.

\section{METODE PENELITIAN}

Penelitian ini merupakan penelitian Expost facto (pengukuran setelah kejadian), karena data penelitian baik variabel bebas maupun variabel telah terjadi sebelum penelitian ini diadakan. Ditinjau dari pendekatannya penelitian ini termasuk pendekatan kuantitatif dengan rancangan kausal korelasional karena dalam penelitian ini mencoba mengetahui hubungan sebab akibat yang titik beratnya pada variabel yang dikorelasikan. Secara umum dari kegiatan penelitian ini dirancang melalui beberapa tahapan. Diawali dengan langkah penelitian pendahuluan untuk memperoleh gambaran awal terhadap topik permasalahan yang akan diteliti. Kemudian dilakukan upaya untuk mengidentifikasi permasalahan yang akan diteliti. Untuk mendukung persiapan maka sebelumnya juga dilakukan pengumpulan berbagai konsep dan teori melalui cara studi pustaka serta observasi secara langsung ke lapangan. Langkah selanjutnya adalah menyususn desain kuesioner yang nantinya dipakai untuk menjaring data dari masing-masing responden. Untuk menghindari kesalahan yang bersifat teknis serta sebagai kelengkapan dalam peritungan maka sebelumnya dilakukan uji validitas dn uji reliabilitas. Selanjutnya dilakukan upaya pengumpulan data awal yang relevan Jurnal Administrasi Pendidikan Indonesia | 58 
dengan permasalahan yang akan diteliti. Berbagai data yang diperoleh tersebut kemudian dilakukan identifikasi untuk memilah-milah data yang benar-benar bermanfaat.

Untuk memenuhi kualitas isinya, terlebih dahulu dilakukan expert judgment oleh dua pakar guna mendapatkan kualitas tes yang baik. setelah itu dilakukan uji coba instrumen untuk mengetahui kesahihan (validitas dan keterandalan (reliabilitas) dengan bantuan program Microsoft Excel.

Populasi penelitian ini adalah semua guru SMA Negeri 1 Mengwi dengan jumlah 70 orang. Pengambilan sampel dilakukan dengan studi sensus, yaitu keseluruhan guru SMA Negeri 1 Mengwi digunakan sebagai sampel. Penelitian ini menggunakan rancangan expost facto. Data dikumpulkan dengan kuesioner dan lembar observasi. Data dianalisis dengan regresi, korelasi dan analisis determinasi.

Data dikumpulkan dengan metode observasi, dokumentasi dan kuesioner meliputi : Gaya kepemimpinan ( $\mathrm{X}$ ), Kompetensi profesional (X ), kompetensi manajerial kepala sekolah $(\mathrm{X})$, dan variabel terikatnya adalah motivasi kerja $(\mathrm{Y})$.

Untuk memenuhi kualitas isinya, terlebih dahulu dilakukan expert judgment oleh dua pakar guna mendapatkan kualitas tes yang baik. setelah itu dilakukan uji coba instrument untuk mengetahui kesahihan (validitas dan keterandalan (reliabilitas) dengan bantuan program Microsoft Excel.

Untuk memenuhi kualitas isinya, terlebih dahulu dilakukan expert judgment oleh dua pakar guna mendapatkan kualitas tes yang baik. setelah itu dilakukan uji coba instrument untuk mengetahui kesahihan (validitas dan keterandalan (reliabilitas) dengan bantuan program Microsoft Excel.

A. Hasil Uji Validitas Isi Instrumen Penelitian

Dari hasil uji validitas isi kuesioner Gaya kepemimpinan kepala sekolah $\left(\mathrm{X}_{1}\right)$, kompetensi profesional $\left(\mathrm{X}_{2}\right)$ kompetensi manajerial kepala sekolah $\left(\mathrm{X}_{3}\right)$, dan motivasi kerja guru $(\mathrm{Y})$, diperoleh semua butir relevan dengan nilai content validity sebesar 1,000. Berdasarkan hasil analisis uji coba kuesioner sebagai berikut

1) Gaya kepemimpinan dari 31 butir kuesioner, semuanya memenuhi syarat (valid), 2) Untuk kuesioner kompetensi profesional dari 37 butir kuesioner, 35 butir yang memenuhi syarat (valid), 3) Untuk kuesioner kompetensi manajerial kepala sekolah dari 40 butir kuesioner semuanya memenuhi syarat (valid), 4) Untuk kuesioner motivasi kerja dari 40 butir kuesioner, 39 butir kuesioner memenuhi syarat (valid). Rangkuman hasil analisis uji validitas isi instrumen penelitian disajikan pada tabel 1.

Tabel 1.

Hasil Uji Validitas Instrumen Penelitian

\begin{tabular}{|c|c|c|}
\hline Variabel & Valid & Tidak Valid \\
\hline $\mathrm{X}_{1}$ & 31 & - \\
\hline $\mathrm{X}_{2}$ & 35 & 2 \\
\hline $\mathrm{X}_{3}$ & 40 & - \\
\hline $\mathrm{Y}$ & 39 & 1 \\
\hline
\end{tabular}

\section{B. Uji Reliabilitas}

Berdasarkan hasil analisis uji reliabilitas instrumen penelitian Gaya kepemimpinan kepala sekolah $\left(\mathrm{X}_{1}\right)$, Kompetensi profesional $\left(\mathrm{X}_{2}\right)$, Kompetensi manajerial kepala sekolah $\left(\mathrm{X}_{3}\right)$, dan Motivasi kerja $(\mathrm{Y})$ dengan menggunakan rumus Aplha Cronbach didapatkan nilai reliabilitas Gaya kepemimpinan kepala sekolah $\left(X_{1}\right)$ sebesar $r 11=0,925$ dengan butir pertanyaan sebanyak 31 dengan katagori sangat tinggi, nilai reliabilitas Kompetensi profesional $\left(\mathrm{X}_{2}\right)$ sebesar $\mathrm{r} 11=0,945$ dengan butir pertanyaan sebanyak 35 dengan katagori 
sangat tinggi, nilai reliabilitas Kompetensi manajerial kepala sekolah $\left(\mathrm{X}_{3}\right)$ sebesar $\mathrm{r} 11=$ 0,934 dengan butir pertanyaan sebanyak 40 dengan katagori sangat tinggi dan nilai reliabilitas Motivasi kerja ( $\mathrm{Y}$ ) sebesar $\mathrm{r} 11=0,936$ dengan butir pertanyaan sebanyak 39 dengan katagori sangat tinggi. Rangkuman hasil analisis uji reliabilitas instrumen penelitian disajikan pada tabel 2 .

Tabel 2.

Hasil Uji Validitas Instrumen Penelitian

\begin{tabular}{|c|c|c|c|}
\hline Variabel & $\begin{array}{c}\text { Total } \\
\text { Item }\end{array}$ & $\mathrm{r}_{11}$ & Kategori \\
\hline $\mathrm{X}_{1}$ & 31 & 0,925 & Sangat Tinggi \\
\hline $\mathrm{X}_{2}$ & 35 & 0,945 & Sangat Tinggi \\
\hline $\mathrm{X}_{3}$ & 40 & 0,934 & Sangat Tinggi \\
\hline $\mathrm{Y}$ & 39 & 0,936 & Sangat Tinggi \\
\hline
\end{tabular}

Data penelitian ini dianalisis secara bertahap, meliputi : deskripsi data, uji prasyarat, dan uji hipotesis. Uji prasyarat yang dilakukan adalah uji normalitas sebaran data, uji linieritas, uji multikolinieritas, uji autokorelasi, dan uji heterokedastisitas. pengujian prasyarat analisis seluruhnya menggunakan bantuan program SPSS 16.0 for Windows.

Hipotesis dalam penelitian ini, yaitu : 1) terdapat kontribusi signifikan antara gaya kepemimpinan dengan motivasi kerja guru SMA Negeri 1 Mengwi, 2) terdapat kontribusi signifikan antara kompetensi profesional terhadap motivasi kerja guru SMA Negeri 1 Mengwi, 3) terdapat kontribusi signifikan antara kompetensi manajerial kepala sekolah dengan motivasi kerja guru SMA Negeri 1 Mengwi, dan 4) terdapat kontribusi signifikan secara simultan antara gaya kepemimpinan, kompetensi profesional dan kompetensi manajerial kepala sekolah dengan motivasi kerja guru SMA Negeri 1 Mengwi.

Penelitian ini bertujuan untuk mengetahui besarnya kontribusi gaya kepemimpinan, kompetensi profesional, dan kompetensi manajerial kepala sekolah terhadap motivasi kerja SMA Negeri 1 Mengwi secara terpisah maupun simultan.

Pengujian hipotesis dalam penelitian menggunakan teknik analisis regresi. Untuk menguji hipotesis pertama, kedua, dan ketiga digunakan teknik analisis regeresi sederhana, sedangkan untuk keempat digunakan teknik analisis regresi ganda dan korelasi parsial. Untuk mengetahui kuat lemahnya hubungan yang terjadi antara variabel bebas dengan variabel terikat digunakan korelasi product moment.

\section{HASIL PENELITIAN DAN PEMBAHASAN}

Berdasarkan uji normalitas data, diperoleh hasil bahwa semua data yaitu gaya kepemimpinan, kompetensi profesional, dan kompetensi manajerial kepala sekolah terhadap motivasi kerja berdistribusi normal dengan harga dari $p=0,197-0,200$ atau $p>0,05$. Sedangkan untuk pengujian linieritas menggunakan bantuan SPSS 16.0 dengan $p>0,05$ berarti semua variable mempunyai hubungan linier. Dari uji multikolinieritas diperoleh data koefisien korelasi dari 0,325 sampai 0,621 , semuanya dibawah 0,800 berarti tidak terjadi multikolinieritas. Uji heteroskedastisitas diperoleh hubungan $Y$ atas $X_{1}, X_{2}, X_{3}$ tidak ada pola yang jelas, serta titik-titik menyebar di atas dan di bawah angka 0 pada sumbu $Y$, maka tidak terjadi heteroskedastisitas. Sedangkan dari uji autokurelasi diperoleh koefisien DurbinWatson besarnya 2,175 mendekati 2 artinya tidak terjadi autokorelasi.

Mengacu pada uji prasyarat, yakni uji normalitas sebaran data, uji linieritas, uji multikolinieritas, uji autokorelasi, dan uji heterokedastisitas, dapat disimpulkan bahwa data dari semua data memenuhi syarat yaitu data normal, semua data mempunyai hubungan linier, tidak terjadi multikolinieritas, tidak terjadi heteroskedastisitas, dan tidak terjadi autokorelas. Dengan demikian uji hipotesis dengan analis is regresi dapat dilakukan. 
Berdasarkan hasil pengujian hipotesis menggunakan analisis regresi dan determinasi menggunakan bantuan program SPSS versi 16.00 diperoleh hasil sebagai berikut.

Rekapitulasi hasil penelitian tentang Rangkuman Statistik Deskriptif Variabel Gaya kepemimpinan kepala sekolah, Kompetensi profesional, Kompetensi manajerial kepala sekolah, dan Motivasi kerja dapat dilihat seperti Tabel 3.

Tabel 3 Rangkuman Statistik Deskriptif Variabel Gaya kepemimpinan kepala sekolah, Kompetensi profesional, Kompetensi manajerial kepala sekolah, dan Motivasi kerja

\begin{tabular}{|l|r|r|r|r|}
\hline \multicolumn{1}{|c|}{ Variabel } & \multicolumn{1}{c|}{$\mathrm{X}_{1}$} & \multicolumn{1}{c|}{$\mathrm{X}_{2}$} & \multicolumn{1}{c|}{$\mathrm{X}_{3}$} & \multicolumn{1}{c|}{$\mathrm{Y}$} \\
\hline Statistik & & & & \\
\hline Rerata (mean) & 121,243 & 135,429 & 154,200 & 152,257 \\
\hline Median & 122,500 & 137,000 & 156,000 & 154,000 \\
\hline Modus & 114,000 & 128,000 & 170,000 & 160,000 \\
\hline Std. Deviasi & 9,959 & 18,059 & 16,963 & 14,498 \\
\hline Varians & 99,172 & 326,133 & 287,757 & 210,194 \\
\hline Range & 38,000 & 73,000 & 61,000 & 54,000 \\
\hline Skor maksimum & 139,000 & 174,000 & 185,000 & 177,000 \\
\hline Skor minimum & 101,000 & 101,000 & 124,000 & 123,000 \\
\hline Jumlah & 8487,000 & 9480,000 & 10794,000 & 10658,000 \\
\hline
\end{tabular}

Berdasarkan tabel 3. rata-rata skor gaya kepemimpinan adalah 121,243 skor minimum yang dicapai adalah 101 sedangkan skor maksimumnya adalah 139. Kompetensi profesional nilai rata-rata variabelnya adalah 135,429 skor minimumnya 101, dan skor maksimumnya 174. Nilai rata-rata variabel kompetensi manajerial Kepala Sekolah 154,200 skor minimum 124 dan skor maksimumnya adalah 185. motivasi kerja guru nilai rata-rata variabelnya adalah : 152,257 Skor minimumnya 123 dan skor maksimumnya 177.

Berdasarkan hasil pengujian hipotesis menggunakan analisis regresi dan kontribusi menggunakan bantuan program SPSS versi 16.00 diperoleh beberapa temuan hasil, sebagai berikut.

Temuan pertama, menunjukkan bahwa terdapat kontribusi yang signifikan antara gaya kepemimpinan terhadap motivasi kerja guru melalui persamaan garis regresi $\hat{\mathrm{Y}}=33,659+$ $0,978 \mathrm{X}_{1}$ seperti tabel 4 berikut ini.

Tabel 4. Uji Signifikansi dan Kelinieran Regresi Motivasi Kerja atas Gaya Kepemimpinan

\begin{tabular}{|l|c|c|c|c|c|}
\hline \multicolumn{1}{|c|}{$\begin{array}{c}\text { Sumber } \\
\text { Variasi }\end{array}$} & Dk & JK & RJK & $F_{\text {hitung }}$ & Sig. / P \\
\hline Total & 69 & 14503,371 & - & - & \\
\hline Regresi (reg) & 1 & 6547,641 & 6547,641 & $\left.55,965^{*}\right)$ & 0,000 \\
Residu (res) & 68 & 7955,731 & 116,996 & - & \\
\hline Tuna Cocok & 32 & 3169,989 & 99,062 & $0,745^{\text {ns }}$ & 0,799 \\
Galat & 36 & 4785,742 & 132,937 & & \\
\hline
\end{tabular}

Dari tabel 4 diperoleh bahwa $F_{\text {reg }}=55,965 \quad(p<0,05)$ adalah signifikan dan linier. Ini menunjukkan bahwa tterdapat kontribusi yang signifikan antara gaya kepemimpinan terhadap motivasi kerja guru melalui persamaan garis regresi $\hat{\mathrm{Y}}=33,659+0,978 \mathrm{X}_{1}$ dengan $F_{\text {reg }}=55,965(p<0,05)$. Dalam penelitian ini ditemukan korelasi positif yang signifikan antara gaya kepemimpinan dengan motivasi kerja guru sebesar 0,672 dengan $p<0,05$. Hal ini berarti makin baik gaya kepemimpinan, makin baik motivasi kerja guru. Variabel gaya kepemimpinan dapat menjelaskan makin tingginya motivasi kerja guru sebesar $45,10 \%$. Ini dapat dijadikan suatu indikasi bahwa gaya kepemimpinan dapat dipakai sebagai prediktor Jurnal Administrasi Pendidikan Indonesia | 61 
motivasi kerja guru di SMA Negeri 1 Mengwi atau dengan kata lain bahwa gaya kepemimpinan berkontribusi terhadap motivasi kerja guru di SMA Negeri 1 Mengwi. Sumbangan efektif (SE) variabel gaya kepemimpinan terhadap motivasi kerja

guru sebesar $16,80 \%$. artinya sekitar $16,80 \%$ variasi dalam variabel motivasi kerja guru dapat dijelaskan oleh variabel gaya kepemimpinan, sedangkan sisanya ditentukan oleh variabel lain. Gaya kepemimpinan adalah cara yang gunakan pemimpin dalam mempengaruhi pengikutnya. Menurut Thoha (1995) gaya kepemimpinan merupakan norma perilaku seseorang pada saat orang tersebut mencoba mempengaruhi perilaku orang lain seperti yang ia lihat. Dalam hal ini usaha menselaraskan persepsi di antara orang yang akan mempengaruhi perilaku dengan yang akan dipengaruhi menjadi amat penting kedudukannya. Menurut Nurkolis (2003) gaya adalah sikap, gerak-gerik atau lagak yang menandai cirri seseorang. Berdasarkan pengertian tersebut maka gaya kepemimpinan adalah sikap, atau gerak-gerik yang dipilih oleh seorang pemimpin dalam menjalankan tugas kepemimpinannya. Gaya yang dipakai oleh seorang pemimpin satu dengan yang lainnya berlainan tergantung situasi dan kondisi kepemimpinannya.

Gaya kepemimpinan merupakan suatu pola perilaku seseorang pemimpin yang khas pada saat mempengaruhi anak buahnya, apa yang dipilih oleh pemimpin untuk dikerjakan, cara pemimpin bertindak dalam mempengaruhi anggota kelompok membentuk gaya kepemimpinannya. Secara teoritis telah banyak dikenal gaya kepemimpinan, namun gaya mana yang terbaik tidak mudah untuk ditentukan. Semakin tinggi kepemimpinan yang diduduki oleh seseorang dalam organisasi, nilai bobot strategik dari keputusan yang diambilnya semakin besar. Sebaliknya semakin rendah kedudukan seseorang dalam suatu organisasi, keputusan yang diambilnya pun lebih mengarah kepada hal-hal yang lebih operasional. Terlepas dari keputusan yang diambil, apakah ada kategori strategik, taktis, teknis, atau operasional, semuanya tergolong pada "penentuan arah" dari perjalanan yang hendak ditempuh organisasi.

Penjelasan tersebut lebih memperkokoh kedudukan kepala sekolah dalam menentukan keberhasilan proses pendidikan. Dalam hal ini kualitas kepemimpinan yang dilaksanakan menjadi sangat penting oleh karena laju perkembangan kegiatan/program pendidikan yang ada di setiap sekolah ditentukan oleh arahan, bimbingan serta visi yang ingin dicapai oleh kepala sekolah. Untuk dapat melaksanakan tugas-tugas kepemimpinannya dengan baik, kepala sekolah dituntut memiliki kompetensi yang disyaratkan. Kompetensi ini harus mengacu pada tiga hal sebagai berikut : (1) Menunjuk pada karakteristik pribadi pemimpin yang tercermin pada setiap sikap dan tindakannya, (2) Mengacu pada suatu kemampuan untuk dapat melaksanakan tugas-tugasnya sebagai pemimpin yang diperoleh melalui pendidikan atau pelatihan, (3) Menunjuk kepada suatu kinerja yang bersifat rasional dan memenuhi spesifikasi tertentu dalam melaksanakan tugas.

Hasil penelitian menunjukkan bahwa gaya kepemimpinan memberikan kontribusi yang signifikan dan positif terhadap motivasi kerja guru. Hal ini sesuai dengan penelitian yang dilakukan oleh I Nyoman Sulantra (2013) dengan judul Determinasi Budaya Sekolah, Kemampuan Manajerial Kepala Sekolah, Dan Iklim Sekolah Terhadap Motivasi Kerja Guru Di SMK Negeri 1 Sukawati. Hasil penelitian menunjukkan terdapat determinasi kemampuan manajerial kepala sekolah terhadap motivasi kerja guru di SMK Negeri 1 Sukawati dengan determinasi sebesar $23,8 \%$

Temuan kedua menunjukkan bahwa terdapat kontribusi yang signifikan antara kompetensi profesional terhadap motivasi kerja guru melalui persamaan garis regresi: $\hat{\mathrm{Y}}=$ $74,952+0,571 X_{2}$. seperti tabel 5 berikut ini. 
JAPI, Vol. 9 No. 1, Bulan April Tahun 2018

ISSN: 2613-9561

Tabel 5. Uji Signifikansi Dan Kelinieran Regresi Motivasi Kerja atas Kompetensi Profesional

\begin{tabular}{|l|r|r|r|c|c|}
\hline \multicolumn{1}{|c|}{$\begin{array}{c}\text { Sumber } \\
\text { Variasi }\end{array}$} & Dk & JK & RJK & F $_{\text {hitung }}$ & Sig. $/ P$ \\
\hline Total & 69 & 14503,371 & - & - & \\
\hline Regresi (reg) & 1 & 7332,370 & 7332,370 & $\left.69,530^{*}\right)$ & 0,000 \\
Residu (res) & 68 & 7171,002 & 105,456 & - & \\
\hline Tuna Cocok & 37 & 2865,118 & 77,436 & $\left.0,557^{\text {ns }}\right)$ & 0,955 \\
Galat & 31 & 4305,883 & 138,899 & & \\
\hline
\end{tabular}

Dari tabel 5 diperoleh bahwa $F_{\text {reg }}=69,530(p<0,05)$ adalah signifikan dan linier. Dalam penelitian ini ditemukan korelasi positif yang signifikan antara kompetensi profesional dengan motivasi kerja guru sebesar 0,711 $(p<0,05)$ dengan kontribusi sebesar 50,60\%. Ini berarti, makin baik kompetensi profesional, maka makin baik pula motivasi kerja guru. Variabel kompetensi profesional dapat menjelaskan makin tingginya motivasi kerja guru sebesar 50,60 \%, ini dapat dijadikan suatu indikasi bahwa kompetensi profesional berkontribusi terhadap motivasi kerja guru di SMA Negeri 1 Mengwi. Sumbangan efektif (SE) variabel kompetensi profesional terhadap motivasi kerja guru sebesar 30,40\%. artinya sekitar 30,40 \% variasi dalam variabel motivasi kerja guru dapat dijelaskan oleh variabel kompetensi profesional, sedangkan sisanya ditentukan oleh variabel lain.

Kompetensi profesional merupakan kemampuan yang berkenaan dengan penguasaan materi pembelajaran bidang studi secara luas dan mendalam yang mencakup penguasaan substansi isi materi kurikulum mata pelajaran di sekolah dengan substansi keilmuan yang menaungi materi kurikulum tersebut, serta menambah wawasan keilmuan sebagai guru. Secara rinci masing-masing elemen kompetensi tersebut memiliki sub kompetensi dan indikator esensial sebagai berikut: (1) menguasai substansi keilmuan sosial dan ilmu lain yang terkait bidang studi. Sub kompetensi ini memiliki indikator esensial: memahami materi ajar yang ada dalam kurikulum sekolah, memahami struktur, konsep dan metode keilmuan yang menaungi atau koheren dengan materi ajar, memahami hubungan konsep antar mata pelajaran terkait dan menerapkan konsep-konsep keilmuan dalam kehidupan sehari-hari; dan (2) menguasai langkah-langkah penelitian dan kajian kritis untuk menambah wawasan dan memperdalam pengetahuan/ materi bidang studi. Bila guru telah mengusai substansi materi pembelajaran maka diduga kemampuan guru dalam mengelola proses pembelajaran akan meningkat. Dari sekian indikator nampak jelas bahwa kompetensi profesional guru diduga berkontribusi terhadap pelaksanaan pembelajaran.

Dengan demikian, sangatlah tepat bila variabel kompetensi profesional dilibatkan dalam penelitian ini dan telah terbukti bahwa kompetensi profesional mempunyai kontribusi yang positif dan signifikan dengan motivasi kerja guru. Dengan demikian dugaan yang menyatakan bahwa terdapat kontribusi yang positif dan signifikan antara kompetensi profesional dengan motivasi kerja guru telah terbukti dalam penelitian ini. Hasil penelitian ini sesuai dengan penelitian yang dilakukan oleh Sriyatim (2012) dengan judul penelitian Kontribusi Kompetensi Profesional Guru, Iklim Organisasi dan Persepsi Guru tentang Kepemimpinan Kepala Sekolah terhadap Motivasi Kerja Guru dan Kinerja Sekolah (Studi Kasus SMA se-Kabupaten Blora).

Temuan ketiga menunjukkan bahwa terdapat kontribusi yang signifikan antara kompetensi manajerial Kepala Sekolah terhadap motivasi kerja guru guru melalui persamaan garis regresi $\hat{\mathrm{Y}}=68,868+0,541 \mathrm{X}_{3}$. seperti tabel 6 berikut ini. 
Tabel 6. Uji Signifikansi dan Kelinieran Regresi Motivasi kerja atas kompetensi manajerial kepala sekolah

\begin{tabular}{|l|r|r|c|c|c|}
\hline \multicolumn{1}{|c|}{$\begin{array}{c}\text { Sumber } \\
\text { Variasi }\end{array}$} & \multicolumn{1}{c|}{$\mathrm{dk}$} & \multicolumn{1}{c|}{ JK } & RJK & F $_{\text {hitung }}$ & Sig. / P \\
\hline Total & 69 & 14503,371 & - & - & \\
\hline Regresi (reg) & 1 & 5806,628 & 5806,628 & $\left.45,402^{*}\right)$ & 0,000 \\
Residu (res) & 68 & 127,893 & 127,893 & - & \\
\hline Tuna Cocok & 38 & 5094,577 & 134,068 & $1,117^{\text {ns }}$ & 0,381 \\
Galat & 30 & 3602,167 & 120,072 & & \\
\hline
\end{tabular}

Dari tabel 6 diperoleh bahwa $F_{\text {reg }}=45,402(p<0,05)$ adalah signifikan dan linier. Dalam penelitian ini ditemukan korelasi positif yang signifikan antara kompetensi manajerial Kepala Sekolah dengan motivasi kerja guru sebesar 0,633 $(p<0,05)$ dengan kontribusi sebesar $39,20 \%$. Hal ini berarti makin tinggi kompetensi manajerial Kepala Sekolah , maka makin tinggi pula motivasi kerja guru. Variabel kompetensi manajerial Kepala Sekolah dapat menjelaskan makin tingginya motivasi kerja guru sebesar 39,20\%, ini dapat dijadikan sebagai indikasi bahwa kompetensi manajerial Kepala Sekolah berkontribusi dengan motivasi kerja guru di SMA Negeri 1 Mengwi. Sumbangan efektif (SE) variabel kompetensi manajerial Kepala Sekolah terhadap motivasi kerja guru sebesar 24,90 \%. Artinya sekitar $24,90 \%$ variasi dalam variabel motivasi kerja guru dapat dijelaskan oleh variabel kompetensi manajerial Kepala Sekolah, sedangkan sisanya ditentukan oleh variabel lain

Ketrampilan manajerial kepala sekolah yang melatarbelakangi seorang kepala sekolah merupakan faktor dominan dalam melaksanakan tugas yang secara penuh menjadi tanggung jawabnya. Kemampuan dan kedewasaan serta keahlian dalam merencanakan, mengendalikan dan melakukan fungsi pengawasan agar tugas-tugas yang diberikan dapat mencapai target yang ditentukan.

Mengingat begitu pentingnya peranan kemampuan manajerial kepala Sekolah dalam upaya peningkatan mutu pendidikan maka selayaknyalah kemampuan manajerial kepala sekolah tersebut ditingkatkan, dibina dengan baik,dan terus menerus sehingga benar-benar memiliki kemampuan yang sesuai dengan tuntutan profesinya.

Seorang kepala sekolah memiliki sifat-sifat bawaan yang membedakannya dari yang bukan pemimpin. Pendekatan-pendekatan yang berupa pola perilaku yang khas yang dilakukan kepala sekolah dalam memimpin instansi pendidikan pada saat mempengaruhi anak buahnya yaitu guru dan stafnya, apa yang dipilih oleh kepala sekolah untuk dikerjakan, cara kepala sekolah bertindak dalam mempengaruhi bawahannya membentuk kemampuan manajerial.

Dari sekian indikator nampak jelas bahwa kemampuan manajerial Kepala Sekolah secara signifikan berdeterminasi terhadap motivasi kerja guru. Hal ini sesuai dengan hasil penelitian yang dilakukan oleh Sri Utami (2012) dengan judul penelitian Kontribusi Antara Kemampuan Manajerial Kepala Sekolah, Etos Kerja, dan Motivasi Kerja Terhadap Kinerja Guru SMP Negeri Di Kecamatan Kuta. Hasil penelitian menunjukkan terdapat kontribusi yang positif dan signifikan antara kemampuan manajerial Kepala Sekolah terhadap kinerja guru melalui persamaan garis regresi $\hat{\mathrm{Y}}=48,602+0,577 \mathrm{X}_{1}$ dengan kontribusi sebesar 44 $\%$ dan sumbangan efektif sebesar $24,7 \%$

Temuan keempat menunjukkan bahwa terdapat kontribusi yang signifikan secara bersama-sama antara gaya kepemimpinan, kompetensi profesional, dan kompetensi manajerial Kepala Sekolah terhadap motivasi kerja guru melalui persamaan garis regresi $\hat{\mathrm{Y}}$ $=9,659+0,364 X_{1}+0,343 X_{2}+0,337 X_{3}$ dengan $F_{r e g}=56,991(p<0,05)$. Ini berarti secara bersama-sama variabel gaya kepemimpinan, kompetensi profesional, dan kompetensi manajerial Kepala Sekolah dapat menjelaskan tingkat kecenderungan motivasi kerja guru di SMA Negeri 1 Mengwi. Dengan kata lain bahwa gaya kepemimpinan, kompetensi profesional, dan kompetensi manajerial Kepala Sekolah berkontribusi dengan motivasi kerja 
guru di SMA Negeri 1 Mengwi. Dari hasil analisis juga diperoleh koefisien korelasi ganda sebesar 0,849 dengan $p<0,05$. Ini berarti, secara bersama-sama gaya kepemimpinan, kompetensi profesional, dan kompetensi manajerial Kepala Sekolah berkontribusi positif dengan motivasi kerja guru di SMA Negeri 1 Mengwi sebesar $72,10 \%$ artinya sekitar 72,10 $\%$ variasi dalam variabel motivasi kerja guru dapat dijelaskan oleh variabel gaya kepemimpinan, kompetensi profesional, dan kompetensi manajerial Kepala Sekolah sedangkan sisanya ditentukan oleh variabel lain yang tidak diteliti. Makin tinggi gaya kepemimpinan, makin baik kompetensi profesional, dan makin tinggi kompetensi manajerial Kepala Sekolah, makin tinggi pula motivasi kerja guru. Bila dilihat koefisien kontribusi ketiga variabel tersebut, tidak sepenuhnya bahwa variabel-variabel tersebut dapat memprediksikan motivasi kerja guru.

\section{PENUTUP}

Berdasarkan analisis dan pembahasan seperti yang telah dipaparkan pada bagian sebelumnya, maka dapat disimpulkan beberapa hal sebagai berikut.

Pertama, Terdapat kontribusi yang signifikan antara gaya kepemimpinan terhadap motivasi kerja guru melalui persamaan garis regresi $\hat{\mathrm{Y}}=33,659+0,978 \mathrm{X}_{1}$ dengan kontribusi sebesar $45,10 \%$ dan sumbangan efektif sebesar $16,80 \%$.

Kedua, kontribusi yang signifikan antara kompetensi profesional terhadap motivasi kerja guru melalui persamaan garis regresi: $\hat{\mathrm{Y}}=74,952+0,571 \mathrm{X}_{2}$ dengan kontribusi sebesar $50,60 \%$ dan sumbangan efektif sebesar $30,40 \%$

Ketiga, kontribusi yang signifikan antara kompetensi manajerial Kepala Sekolah

terhadap motivasi kerja guru melalui persamaan garis regresi $\hat{\mathrm{Y}}=68,868+0,541 \mathrm{X}_{3}$ dengan kontribusi sebesar 39,20\% dan sumbangan efektif sebesar $24,90 \%$..

Keempat, kontribusi yang signifikan secara bersama-sama antara gaya kepemimpinan, kompetensi profesional, dan kompetensi manajerial Kepala Sekolah terhadap motivasi kerja guru melalui persamaan garis regresi $\hat{Y}=9,659+0,364 X_{1}+0,343$ $\mathrm{X}_{2}+0,337 \mathrm{X}_{3}$ dengan kontribusi sebesar $72,10 \%$.

Berdasarkan kesimpulan dan implikasi penelitian yang telah dipaparkan di atas, maka dapat disarankan beberapa hal yaitu sebagai berikut.

Bagi guru, beberapa hal yang perlu diperhatikan guru SMA Negeri 1 Mengwi adalah 1) lebih meningkatkan kemampuan dalam meningkatkan potensi / kemampuan diri sesuai dengan bidangnya, 2) Guru sebaiknya lebih teratur dalam mengelola waktu kerja, memenjaga kondisi kerja yang kondusif dan lebih teratur dalam mengelola waktu, 3) Tenaga pengajar harus lebih tepat waktu dalam bekerja, misalnya masuk kantor lebih awal, pulang kantor tepat waktu, dan 4) Guru harus meningkatkan ketaatan dengan mematuhi aturan kantor, antara lain memakai seragam dinas sesuai jadwal.

Bagi Kepala SMA Negeri 1 Mengwi adalah mengintensifkan kemampuan manjerialnya, khususnya yang berkaitan dengan guru. Misalnya kepala sekolah memberikan pembinaan kepada guru mengenai pembuatan silabus sesuai kurikulum yang ada sehingga guru akan dapat melakukan tugasnya dengan optimal dan dapat mencapai tujuan organisasi yang telah dirumuskan oleh sekolah sehingga terciptanya pendidikan yang berkualitas.

Bagi praktisi, secara empirik ditemukan bahwa variabel gaya kepemimpinan, kompetensi profesional, dan kompetensi manajerial kepala sekolah berkontribusi secara signifikan terhadap motivasi kerja di SMA Negeri 1 Mengwi. Ini menunjukkan bahwa ketiga variabel tersebut sudah sepenuhnya berhubungan dengan motivasi kerja. Namun demikian perlu diadakan penelitian lebih lanjut tentang berbagai faktor yang diduga berdeterminasi terhadap motivasi kerja SMA Negeri 1 Mengwi. Dengan dilibatkannya variabel-variabel lain tersebut akan menambah referensi dan dapat dimanfaatkan sebagai pijakan untuk melakukan perbaikan-perbaikan guna meningkatkan motivasi kerja SMA Negeri 1 Mengwi. 


\section{DAFTAR PUSTAKA}

Buford J.A. dan Athur G. Bedeian. 1988. Management In Extension (2Edition). Alabama: Alabama Cooperative Extension Swrvice, Aurburn University.

Hersey, Paul dan Ken Blanchard, 2000. Manajemen Perilaku Organisasi, Pendayagunaan Sumber Daya Manusia. Penerjemah : Agus Dharma Jakarta: Penerbit Erlangga.

Hoy, W.K., Miskel C.G. 1987. Educational Administration Theory, Research and Practice. Third Edition. Random House New York.

Luthans. 1981. Organizational Behaviour. New York: McGraw-Hill Book Company.

M. Ngalim Purwanto. 1987. Psikologi Pendidikan. Remadja Karya, Bandung.

Sardiman. 1990. Interaksi dan Motivasi Belajar Mengajar. Penerbit : CV. Rajawali Pers. Jakarta.

Satori, Djam'an. 2000. Reposisi Kepengawasan Pendidikan menurutPP 25 tahun 2000. Makalah dalam seminar supervisi pendidikan di kecamatan Surade.

Soemadi Soerjabrata. 1981. Psikologi Pendidikan. Yogyakarta : Rake Press.

Siagian, Sondang P, 1992.Manajemen Sumber Daya Manusia. Jakarta : Bumi Aksara

Sri Utami. 2012. Kontribusi Antara Kemampuan Manajerial Kepala Sekolah, Etos Kerja, dan Motivasi Kerja Terhadap Kinerja Guru SMP Negeri Di Kecamatan Kuta. Tesis. Pasca sarjana Undiksha Singaraja.

Sriyatim. 2012. Kontribusi Kompetensi Profesional Guru, Iklim Organisasi dan Persepsi Guru tentang Kepemimpinan Kepala Sekolah terhadap Motivasi Kerja Guru dan Kinerja Sekolah (Studi Kasus SMA se-Kabupaten Blora).Tesis. Program Pascasarjana Universitas Muhammadiya Surakarta.

Steers, R. M., \& Porter, L. W. 1983. Motivation and Work Behavior. Edisi Ke-3. New York : McGraw Hill Book Company.

Sulantra I Nyoman. 2013. Determinasi Budaya Sekolah, Kemampuan Manajerial Kepala Sekolah, Dan Iklim Sekolah Terhadap Motivasi Kerja Guru Di SMK Negeri 1 Sukawati. Jurnal Vol 4 No.1. Pascasarjana Undiksha Singaraja. 